\title{
Will the real specialist please stand up? Characterising early craft specialisation, a comparative approach for Neolithic Anatolia
}

\author{
Emma Baysal \\ British Institute at Ankara, TR \\ emmabaysal@gmail.com
}

\begin{abstract}
The Neolithic period saw changes in production practices and the roles of individuals that were important in the development of increasing social differentiation. Although there is evidence of specialised manufacturing in Neolithic Anatolia, the dynamics of changing production and accompanying social effects have not been characterised. This article looks at how specialisation might be defined and identified in the Neolithic period in Anatolia using the results of recent theoretical debates as a starting point. It addresses the possibility of comparing the various forms taken by early non-institutionalised specialisations and argues the importance of considering this subject as a major element in emerging social complexities.

IZVLEČEK - V obdobju neolitika so se spremenile proizvodne prakse in vloge posameznikov v družbi, ki so bile pomembne pri oblikovanju vedno večje družbene razslojenosti. Dinamika spreminjajoče se produkcije in družbenih učinkov, ki jo spremljajo, še niso bili opisani, kljub dokazom o obstoju specializirane proizvodnje v neolitiku v Anatoliji. V članku predstavljam, na kakšen način bi lahko definirali in prepoznali specializacijo $v$ neolitskem obdobju $v$ Anatoliji, pri čemer se opiram na rezultate sodobnih teoretskih razprav. Poleg tega poskušam primerjati različne oblike proizvodnje, ki so obstajale $v$ zgodnjih ne-institucionaliziranih specializacijah, in dokazujem, zakaj je pomembno, da upoštevamo te različne oblike proizvodnje kot glavni element v razvijajočih se družbenih kompleksnostih.
\end{abstract}

KEY WORDS - craft specialisation; Anatolia; Neolithic; beads; chipped stone; social structure

\section{Introduction}

Archaeologists have traditionally conceptualised and explained the emergence of craft specialisation in the context of various linear evolutionary models of socio-economic development originally proposed by Gordon V. Childe $(1925 ; 1944)$ in the 1920s. Conceptualisations of the Eurasian Neolithic have been fitted into an ethnographically derived developmental framework, which typifies hunter-gatherer and small-scale agriculturalist communities as non-hierarchical, egalitarian societies (Perlès 2001.200; Wiessner 2002). Within these models the first manifestation of craft specialists has been associated with the appearance of metal working in the archaeological record of the Chalcolithic and Early Bronze Age (Rosen 1997.112; David, Kramer 2001.304). It is dur- ing these periods, in the $5^{\text {th }}-3^{\text {rd }}$ millennia $\mathrm{BC}$, that emergent hierarchies and large-scale settlements, that might be termed chiefdoms, and early states in social evolutionary models are believed to appear. In contrast, Pre-Pottery Neolithic and Pottery Neolithic social organisation has been perceived as much simpler, with egalitarian household based production as the modus operandi (Perlès 2001.200; Wiessner 2002). Definitions of craft specialisation have frequently been included in artefact studies by scholars across the globe, some are very region- and period-specific (e.g., Arnold, Munns 1994.497; Kenoyer et al. 1991.45), and many do not give enough detail to address seriously the issues associated with specialisation (e.g., Tosi 1984.23; Stein 1996.25; 
Rice 1981.220). Cathy L. Costin (1991) produced the most comprehensive survey of the possible combinations of circumstances that would allow craft specialisation to take place and the publication by Rowan K. Flad and Zachary X. Hruby (2007) has made further significant contributions. John E. Clark (2007. 20 ) has recently criticised the stagnation of work on craft specialisation in theories developed from systems thinking, neo-evolutionism and holistic views of social change.

Archaeological evidence of the past few decades has made it increasingly clear that the roots of complex stratified societies and their accompanying economic and social conditions lie farther back in prehistory than had previously been acknowledged. Catherine Perlès (2001.226) shows conviction that craft specialisation already existed in the Early Neolithic of Greece, "... what cannot be doubted is that ... the organisation of craft production in the early Neolithic was already differentiated, and that, in some cases, it rested on complex strategies of raw material exploitation". She suggests that in order to further understand this, we should, "...consider all commodities in circulation and systematically compare the parameters that characterise, in each case, the procurement of raw materials, commodity production, site consumption and regional distribution." (Perlès 1992.119). There are now also undisputed examples of Neolithic workshops in Central Anatolia that carried out large-scale manufacture of obsidian products which were then transported long distances to their place of use (Binder 2002. 80; Binder, Balkan-Atl 2001), a phenomenon to which I will return later. There are also signs of differentiation in other aspects of society, such as the building of communal structures that may not have been intended for everyday habitation (Christensen, Warburton 2002; Beyer-Honça 1995). Much of the work on craft specialisation has focussed on its structural form, the time consumed in its practice and whether the practitioners were under the direct control of others. Although part-time and full-time work are concepts familiar to us in the modern world, and usefully considered by authors such as Costin (1991), they are not generally traceable in the Neolithic record and are also not necessarily relevant to the presence or absence of specialisation. Perlès's (1992) positive approach to the possibility of specialisation in the Neolithic sets aside previous preconceptions and provides a starting point from which to form a definition of craft specialisation and methods by which it can be identified. The ethno-archaeological examples discussed by Nicholas David and Carol Kra- mer (2001.316 onwards) show that there are endless social and economic permutations to specialisation that cannot all be adequately codified in a simple textual format. Such variations are even less visible in the archaeological record; therefore, although it is necessary to acknowledge the fact of variation, it is important to understand the limitations of archaeological data.

Archaeological evidence has increasingly pointed to the coexistence of a variety of different specialisations during the Anatolian Neolithic varying from whole communities (Binder, Balkan-Atl 2001) to single individuals (Wright, Bains 2007). A method that encompasses all of these concurrently existing types of specialisation, categorises them and assesses and records their variations is essential in order to usefully discuss their dynamic change and inter- and intra-site variation. In the very specific context of the Neolithic, it is also essential to have a framework within which to situate incipient specialisations. An understanding of the nature of the archaeological evidence available from prehistoric societies is vital to the development of this methodology; the method presented here was developed for application to the Anatolian Neolithic, however, it is designed to be widely applicable and therefore also comparable. The parameters that are suggested are relevant to the Neolithic period and archaeologically identifiable, but not context-specific; terminology such as 'part-time' and 'full-time', which cannot be corroborated, has been avoided. The ideal is that the consistent use of a methodology for characterising specialisation will allow a considered approach to some major questions such as "where and when are the origins of specialisation?', 'how is a workshop area defined?' and 'where are the origins of social differentiation?'. The detailed methodology of current excavation projects lends itself to the identification of the fine-scale in production practices; micro-debitage scatters can be traced, as can small artefacts such as beads, which have an excellent recovery rate through flotation and wet-sieving (Twigger 2009). Indications are that rather than being a bi-product of social complexity, specialisation formed an integral part of its development.

\section{Social structure and craft specialisation}

The assumption of the inherently egalitarian nature of Neolithic society has often been an integral part of interpretations produced in archaeological research (e.g., at Çatalhöyük; Düring 2006). Egalitarianism can be defined as, "...societies that maintain 
equal access of individuals, within age-sex categories, to resources and status positions..." (Wiessner 2002.235), or as many prestige positions in society as there are people to fill them (Fried 1960). Flanagan (1989.248) highlights that there is a difference between equality of opportunity and equality of outcome, and suggests that it may be clearer to use the word autonomy to imply that people were not answerable to anyone else. The association of craft specialisation with a cultural paradigm that includes a specific level of socio-economic 'complexity' (Cross 1993.61; Kenoyer et al. 1991.45) is argued below to preclude discussion of specialisation for certain periods due to the serious underestimation of societies' capabilities. Stateless societies became largely defined by the absence of indicators of modern social complexity (Flanagan 1989.245) and the terms that were used to describe them were not defined in their own right, but only in opposition to complexity and inequality (Chapman 2003.72), "... simple societies are believed to demonstrate their egalitarian nature simply by displaying evidence of a lack of differentiation, and complex societies the inverse." (Rowlands 1989.29).

These ideas came to be described in almost evolutionary terms, implying both natural selection and that human agency and decision-making played a small or non-existent role in this evolutionary process (Boone, Smith 1998.141). The emphasis on hierarchy and accumulation of wealth that has been created by the association of specialisation with complex societies, as opposed to a broader view of other social positions related to community organisation or redistribution of wealth (Bender 1978.212) has only helped to exacerbate the diversion of attention from Neolithic evidence. Salzman (1999.31) advocates the view that there is a continuum between equality and inequality, effectively a sliding scale with no single point at which one can be separated from the other. Michael Rowlands (1989.35) also highlights the fragility of the reach of many early states, suggesting that stateless sub-groups of different structure may have lived under the umbrella of a highly hierarchical society while not participating in its mechanisms.

Institutionalised inequality is seen as the crucial milestone on the road to political development, almost an obstacle on the way to the goal of complexity (Wiessner 2002.233). Partly because of the application of social-anthropological terminology and an approach, which sees social hierarchy and social complexity as being one and the same (Chapman 2003.10), it has been assumed that egalitarian socie- ties were therefore basic and unvarying in every sense. Polly Wiessner's (1995.234) counter argument to this paradigm is that a certain level of differentiation is inherent in every society, because every society, no matter what form it takes, has 'aggrandisers' who take advantage of opportunities. The importance of differentiated social structure in 'egalitarian' societies has only recently come to light. Although it has long been accepted that there are universal divides on the basis of age, sex and kinship (Costin 1986.328; Wiessner 2002.235; Kuijt 1995. 12, 62; Giddens 1984.396), it is only relatively recently that the more complex institutions of 'egalitarian' societies are beginning to be explored in the archaeological literature (e.g., Byrd 2005; Kuijt 1995). John Clark and William J. Parry (1990.320) concur, saying that part-time independent craft specialisation can be found in almost all societies. This is not to imply that there is any inherited inequality or that it necessarily takes any institutionalised form, but it is nonetheless important to acknowledge the possibility and discuss the Neolithic accordingly.

\section{What is craft specialisation?}

An array of attempts has been made to define craft specialisation in specific archaeological examples, as well as in a purely theoretical setting. The latest of these is the collected work published by the American Anthropological Association (2007), which criticises the inconsiderate or inadequate definition or explanation of specialisation in the context in which the term is being used, alluded to by Costin (2007. 147). A selection of the definitions previously used by others quickly highlights their lack of detail:

- "...variability in output per capita for a given product within the population sampled." (Tosi 1984.23);

- "...the regular, repeated provision of some commodity or service in exchange for some other." (Costin 1986.328);

- "...regular production for supplying people or groups beyond the household or near kin unit." (Rosen 1989.107);

- "...the production of goods and services for a broad consumer population, on a (usually) fulltime basis, in order to earn a livelihood." (Stark 1991.64).

Elizabeth M. Brumfiel and Timothy K. Earle (1987.5) describe it as a continuum, with the domestic mode of production at one end and modern industrial economy at the other: 
- "...craft specialisation is production of material objects through modification of raw materials - a creative act of reorganisation that invests the material with information by means of human labour" (Clark, Parry 1990.225), and

- "...fashioning items at volumes above and beyond the needs of the producing individual or group for exchange with those engaged in complementary economic pursuits" (Schortman, Urban 2004.187).

Even the seminal work of Costin which defined specialisation as, "... a differentiated, regularised, permanent, and perhaps institutionalised production system in which producers depend on extra-household exchange relationships at least in part for their livelihood, and consumers depend on them for the acquisition of goods they do not produce themselves." (Costin 1991.4) has recently been criticised by the author herself for focussing on the dominance of elites (Costin 2007.145).

Overall the areas covered by the definitions of specialisation that have previously been used can be summarised in a number of points:

- the amount of time spent on an activity,

- the proportion of subsistence that might be obtained from an activity,

- the attribution of a name or title for the activity and the person doing it,

- payment in money (where applicable) or in kind for the products or exchange of products,

- production beyond the needs of the household or relative volume of production,

- level of knowledge/skill, and

- proportion of households or individuals involved in production.

As Costin (2007.145) succinctly describes, there have been games of 'lexical semantics' and 'phenomenological classification' with regard to how these various aspects are described. While discussing these different facets of specialisation, authors have used the same terms to mean different things; e.g., 'household-based production' and 'independent production' can be interpreted variously or used to characterise a single example. This highlights the need for a careful definition of what is meant by craft specialisation if understanding of the subject is to be improved (Costin 1991.0). This problem is largely the result of approaches generated to apply to individual case studies where authors have concentrated on speci- fic sites or forms of material culture and focussed their definitions accordingly. Examples include work by Prudence M. Rice (1981), Miriam T. Stark (1991) and David Peacock (1982) on pottery manufacture and Leslie A. Quintero and Philip J. Wilke (1995) on lithics.

The recent debate on specialised production published by the American Anthropological Association (2007) gathered a variety of views about the development of specialisation studies over the past decades. Flad and Hruby (2007) and Costin (2007.145) concur in their overviews of the subject that there have been issues in the consistent use and understanding of terminology. Although Flad and Hruby (2007.3) go on to suggest their own definition of specialised production, I concur with Costin (2007.147) in finding the result to be both confusing and complicated, as well as falling largely outside the scope of the archaeological record of the Neolithic period.

The issue of Neolithic specialisation was raised by Perlès (1992.150) in her consideration of Greek examples, from which she concluded that there was 'technically specialised production' which went beyond the need of the community, using know-how that was not shared by all, and provided for the needs of exchange, in the form of village craft specialisation or inter-village household specialisation: the beginnings of social hierarchy. This can almost certainly be characterised as part-time for the Neolithic period; she concludes, "...it is those crafts which demand the longest apprenticeship followed by regular production 'to keep in practice', but which then result in an output far beyond domestic needs, that are characteristically organised into specialized crafts." (Perlès 1992.135).

Despite Perlès' accepting attitude to the idea of incipient specialisations during the Neolithic, craft specialisation has been inextricably linked to a stage of socio-economic development deemed appropriately complex for its viability, as discussed earlier. The implication of an economic impetus for specialist production was that a certain level of 'development' had to be reached and economic elite had to be present in order to pay for goods (Childe 1942.87). Although such an approach is not incompatible with later periods when full time specialists were attached to elite sponsors in the $4^{\text {th }}-3^{\text {rd }}$ millennia calBC, the problem with this approach is that it "drastically $l i$ mits what we can know about the past" (Pyburn 2004.xi, cited in Patterson 2005.330) because the discussion of the emergence of craft specialization 
has been couched largely in terms of a 'cost-benefit' economic framework. Childe recognised that specialisation could take a number of different forms: parttime specialisation, household and village specialisation and full-time professional specialisation (Childe 1958.13). He regarded small-scale specialisation as being essentially a magnification of common skills, whereas professional specialisation entailed special training (and by implication, restricted knowledge) (Childe 1925; 1944).

This implies that there are widely varying levels of commitment to the risk of economic commitment, on a sliding scale, and a 'part-time' or seasonal specialist may have taken only the most minimal risk, or indeed no risk at all, because other members of their household might have continued to produce the food requisite for subsistence. In a non-market economy, everyone is protected in times of need by the communal nature of the arrangement and the loose commitment to production (Wiessner 2002. 235). The question of competition has played an important role in much discussion (see Rice 1981; Tosi 1984) with the general assumption that something more closely resembling the modern western view of the market economy would have rapidly developed and that competition would have been the norm.

The long-standing association of specialisation with the presence of elites has created an inextricable link between specialisation and the terms 'attached' and 'independent'. In her recent article, Costin (2007. 155) makes assertions about the significance of these terms that are not only irrelevant in the context of the Neolithic period, but are actually fundamentally opposed to much of the available evidence. In fact, some of Costin's assertions seem to act as self-fulfilling prophecy, "...by definition, the products of attached specialists serve to up-hold institutionalized sociopolitical differentiation, but the products of independent specialists do not." (Costin 2005. 1072-1073). As neither of the terms is applicable in societies without an institutionalised hierarchy in the Childean sense, they will not be applied here in reference to the Neolithic. Likewise Clark's (2007) suggestion that specialisation should only be treated as a part of technology rather than as a separate phenomenon is useful when specialisation is a known and accepted aspect of the social milieu being discussed. However, in the case of the Neolithic, the identification and characterisation of specialisation are not well defined, especially in its incipient stages, where a more nuanced approach to its definition is essential.
Having established which aspects of specialisation cannot be identified from the archaeological record of the Neolithic period, it is necessary to structure an approach based on the materials and evidence available. Standardisation in 'craft' products may be one of the most fruitful avenues for further research, as it is archaeologically traceable. Fewer producers should mean that there is, by default, less variation in artefacts, and also the repeated production of identical items will economise on time and allow standardisation of the treatment of the raw material (Costin 1991.33). This is one of the only criteria for specialisation that has already been recognised in the Neolithic and has been suggested as indicative of the earliest specialisation (e.g., Conolly 1999; Quintero, Wilke 1995). Increasingly high definition methods of recovering and recording archaeological data mean that it is possible to identify activities at a household level (e.g., Hodder 1996; 2005). François Sigaut (1994.436) has suggested a pragmatic approach to technology in the archaeological record, whereby an artefact should be studied from three different perspectives: the form and construction of the object, how it works and its function. There is an obvious drawback in that the function of an object is often not clear; given that the processes used in the past are now lost to us, analogy with known artefacts may or may not be possible on a case by case basis (Sigaut 1994.436). There are also issues relating to the function as perceived by the manufacturer/user of the artefact as opposed to those understood by the archaeologist.

At the (generally low) levels of production for which there is evidence in the Neolithic, it is possible, contra David and Kramer (2001.305) and Costin (1991. 33), that there was little efficiency to be gained from expending more time on a task. It is possible to argue that efficiency should be seen as the best use of available time, whether for agricultural, pastoral or craft activity. It is possible that particular ways of doing things should be seen as socially significant, "...at its heart, specialisation is ... a cultural activity that is actively created and manipulated." (Conolly 1999.105); market economy conceptions of efficiency are not necessarily relevant in this scenario. James Conolly (1999.104) concluded that craft specialisation becomes so culturally and temporally specific that it can never fully be defined.

Although the situation-specific nature of specialisation is clear from the above discussion, some common strands offer promise in undertaking its systematic characterisation. To summarise, previous the- 
oretical approaches to and discussions of specialisation indicate that a wide variety of parameters for specialisation are not applicable in the context of Neolithic archaeology; they also indicate, however, that there are potential avenues for consideration. The refining of parameters to assess the presence and degree of specialisation to fit the available evidence, and the disregard for aspects such as the proportion of time devoted to an activity, which in most cases is an abstract concept, allows the construction of a framework within which specialisation can be discussed.

\section{Parameters for Anatolian Neolithic specialisa- tion}

Clark's (2007.20) use of the concept "things, persons, action, value and surplus" is a realistic point from which to begin a consideration of Neolithic craft specialisation. However, his contention that craft specialisation should not be considered as an entity in its own right, but only as a facet of production is, as mentioned above, less helpful in a situation where the identification of incipient specialisations has important social and economic connotations. I begin then, from the premise that "Agents made, exchanged, and used a variety of objects in daily practice, and these had different meanings and values that affected social relationships, personhood, and social reproduction." (ibid.).

The criteria for characterising specialisation that I propose are divided into three groups. It is suggested that there were only basic social prerequisites for the development of specialisation and that it had the potential to occur in one form or another in almost any place at any time (characterised by Rosen (1989.111) as, "...incipient and sporadic specialization, not yet institutionalized nor widespread". Dichotomies have previously been a popular method of contrasting different circumstances: for example, full-time/part-time; attached/independent; exotic/utilitarian; and there has been a reliance on questions of presence and absence (of hierarchies, exotic materials, workshop areas, among others). The criteria presented are designed to be viewed as part of a more nuanced sliding scale; skill level, for example, is not necessarily crucial, as production may be based on volume manufacture of products requiring low skill levels. The criteria that have been produced can be used to assess the likelihood of specialisation, given a specific set of archaeologically identified circumstances. The focus is therefore on the scale, significance and plausibility of the various pa- rameters of craft specialisation outlined below; assessment is based on the strength of a range of evidence and is explored below through two case studies. The use of a consistent set of parameters in assessing potential cases of craft specialisation is designed to produce discursive results that are broadly comparable. The system provides for reinterpretation on the basis of new evidence and also allows criticism in an environment of comparability.

Outlined below are the suggested parameters for assessing Neolithic specialisation arranged under three headings: the first refers to conditions that are assumed to have been present for the potential of specialization; the second group refers to the technical aspects of manufacture, and the third to the social conditions that would have motivated and allowed specialised production. These are followed by some example case studies to demonstrate how this system might indicate relative likelihoods and degrees of specialised activity during the Neolithic period.

\section{The system in use}

In order to demonstrate the potential of this approach to characterising craft specialisation, I apply it here to two examples, both taken from Neolithic Anatolia, which are at either end of the 'specialisation scale'. The first is the production of obsidian items at Kaletepe, where the naviform technique was used to produce very specific blades for export to southeast Anatolia and the Levant; the second is the early Neolithic manufacture of stone beads within small communities, using the example of Boncuklu Höyük in central Anatolia (Fig. 1). These examples are broadly contemporary, dating from the late ninth millennium onwards.

\section{Chipped stone - the naviform strategy}

The naviform strategy has long been regarded as one of the best candidates for evidence of early craft specialisation and was suggested by Quintero and Wilke (1995.18) as one of a key set of indicators of socio-economic change that includes the phenomena of sedentism, and domestication of plants and animals. Because of the dominance of blade-based technologies in the Levantine PPNB, largely produced by naviform cores, this technology became a type fossil for the period (Quintero, Wilke 1995.19). Naviform technology was suitable to produce the typical suite of products utilised by PPN communities, sickles with long blades, projectile points, burins, borers, cutting and scraping tools (Quintero, Wilke 1995.20). The 
Prerequisites for Neolithic specialisation:

\section{Surplus:}

In order to participate in this economic activity, a potential consumer must possess, or have the ability to provide, a surplus of some item/good/service with which they are willing to part.

Value:

Whether by locality or social factors, variable by place, season or demand, there must be some form of equivalency in order for exchange (even in gift systems or cases of delayed reciprocity as described by Layton (1997.76) which "...binds the giver and receiver in a continuing social relationship.") to be agreed on. Value in the case of the Neolithic social milieu was perceived and subjective in a way that is not the case in a market economy (Clark 2007.27). The attribution of value does not need to be consistent or non-negotiable as is often the case in modern economies, and could largely have been determined by the supply/demand/abundance of materials and time and could be non-material, such as the attribution of status/kudos to the producer.

\section{Payment:}

Some form of reciprocity is integral to specialisation. The question of the exchange of gifts as a part of social and economic interactions, and the use of 'high value' or 'luxury' goods is difficult to identify archaeologically, but must be acknowledged as a possibility.

\section{Technology and production}

\section{Modification of materials:}

Fundamental to any production for exchange is the modification of a material by one individual in order to produce an item demanded by another. This is the most basic level and may be complicated by the involvement of further stages in procurement and production and the involvement of more individuals. The modification will generally add to the value attributed to the material.

\section{Knowledge/know-how:}

Those conducting the production task would use specific knowledge sets/know-how. This does not imply that others in the community would be excluded from knowledge of these skills and would necessarily be unable to produce similar items themselves.

\section{Repeated production:}

The household (whatever form it may take) must have the capacity to produce more of certain items than it can consume. This necessitates an appropriate length of time being spent on the task and implies that there is enough time available to do so, whether because certain members of the household carry out different economic tasks, or because of seasonal variation in subsistence-related tasks, or because a certain amount of subsistence-related tasks could be substituted by the specialised activities. This could be seasonal/daily/or any combination thereof.

\section{Production based on demand:}

There must be a need for the products in order to create a viable economic situation. This is fundamental to the specialisation question - the desire for the products creates the demand.

\section{Social aspects}

\section{Number of producers fewer than consumers:}

Although obvious it is important to highlight that as specialisation of production becomes more prevalent, the proportion of individuals carrying out any particular production task decreases.

\section{Product function:}

This is key to the concept of demand: a perceived need for an item is required, whether for utilitarian or social reasons items would be ascribed value (as described above) according to their desirability.

\section{Cultural congruency:}

A product will be recognisable to its producer and consumer for reasons of style, form, function or choice of material. This may contribute to a sense of identity through reinforcing community cohesion or by imbuing an item with added value by virtue of its 'exotic' nature, rarity or association with a distant area/community/source. This can be true for purely utilitarian as well as decorative or adornment related items.

\section{Culturally specific typology:}

The consumer will be discerning about the products that they acquire. This would be dependent upon quality, function, style and even fashion. In order for a new technology to spread, it must have been seen to be desirable, whether or not it provided a significant technological or functional advancement.

\section{Tab. 1. Criteria for the characterisation of Neolithic craft specialisation.}


key to the success of this technology was the ability to produce many very consistent and predictable blades from a core without much wastage, although materials such as tabular flint are most suitable to the quick production of a useable core, they were also commonly made from obsidian (such as at Aşıklı Höyük) and other stones (Quintero, Wilke 1995. 20). Quintero and Wilke (1995.26) suggest that, "Many villages comprised population clusters that were substantial in size, large enough to

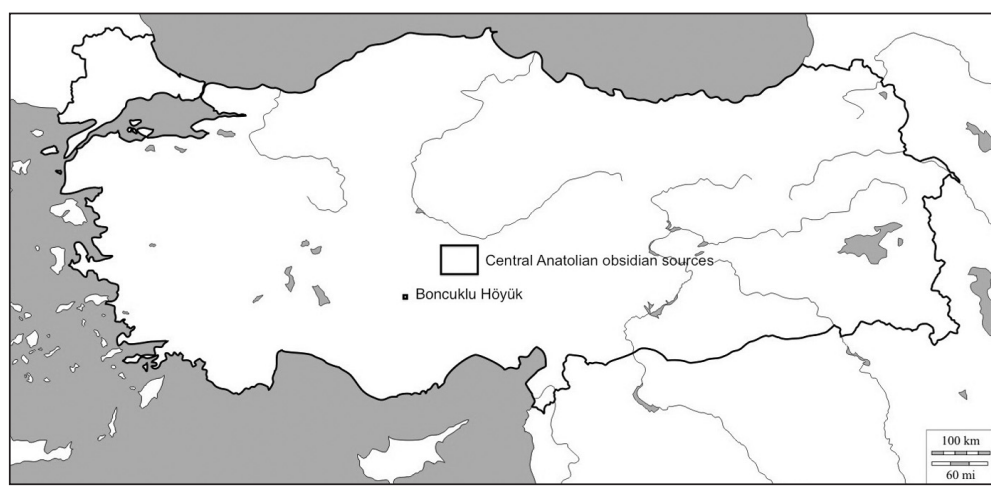

Fig. 1. Location of the sites discussed in the case studies, the obsidian sources of central Anatolia and the site of Boncuklu Höyük. provide an appropriate social and economic setting for a beginning stage of craft specialization. We believe that the villagers in turn required a degree of craft specialization to meet their economic needs."

Few Neolithic specialists would disagree with the first of the above sentences given the current state of evidence; however, it is the second that remains contentious. Quintero and Wilke are absolutely clear in pointing out that one specialised lithic industry does not mean that all lithic production was specialised; indeed, they say that most day-to-day needs could have been met by almost all individuals, and specialisation was only in blades (Quintero, Wilke 1995.27). They also suggest that blade production would not have been the only specialised activity; others may have been burnt lime technology for plastering and the production of white-ware and plaster statuary (Quintero, Wilke 1995.28). They end by arguing that lithic specialisation of this sort was lost in the Pottery Neolithic. The crux of Quintero and Wilkes' (1995.27) argument for specialised production lies in the standardisation of the technique being used and the skill of the manufacturers. Douglas Baird (2001.329) has argued, on the basis of evidence from Jilat, that the Naviform reduction strategy was not inherently specialised on the basis of skill or know-how, but that it may have been specialised in terms of the number of practitioners at some but not all sites $-e . g$., not among desert communities. The example of central Anatolian naviform production using obsidian indicates the possible isolation of a single, highly specialised manufactory in an otherwise less complex production paradigm.

Anatolia has some of the richest sources of obsidian and served a wide area during the Neolithic. The obsidian sources are located on a group of volcanoes, Acıgöl, Göllü Dă̆, Nenezi Dağ, Hasan Dağ and Erciyes Dağ (Balkan-Ath et al. 1999.135). Kömürcü is the most studied of the sources and has the best known of the workshop areas, Kaletepe, which is a large plateau with obsidian in the form of elongated blocks. It is on the northern slope of Göllüdağ at $1600 \mathrm{~m}$ elevation and is about $4 \mathrm{ha}$ in area (Binder, Balkan-Ath 2001.1). Kaletepe is the only workshop to have been excavated and has revealed deposits more than 6m deep (Balkan-Ath et al. 1999.140; Binder, Balkan-Ath 2001.3; Balkan-Ath 2001; Balkan-Atl, Binder 2000; 2001; 2003; Balkan-Atl et al. 1999; 2000; 2003; Balkan-Ath, Binder and Kuzucuoğlu 1999a; 1999b; Balkan-Atl, Binder and Cauvin 1999). Two soundings found workshop waste in situ, and care was taken to try and understand the production sequences of the unipolar, bipolar and bifacial cores. In some layers there appear to be pieces of obsidian which come from sources other than the one at which they were found; the excavators regard these as evidence of the domestic use of the site, as well as its use as a production area (BalkanAth et al. 1999.142). A variety of production sequences is represented at the site, but a 'spectacular' $64.7 \%$ of the cores found at the workshop were standardised naviform cores (known as Kaletepe naviform), which were used for the production of long pointed blades which were exported to other sites (Balkan-Ath et al. 1999.138; Binder, Balkan-Ath 2001.1; Balkan-Ath et al. 2001. 41). Balkan-Atl et al. conclude that, "Kaletepe can be considered as a specialists' workshop where an intensive production of regular long pointed blades designated to exportation took place." (2001.41).

The typical products of the workshop were long blades of about $15 \mathrm{~cm}$, all of which were exported, even some of the by-product upsilon blades and lateral blades were also exported. These products are characteristic of the PPNB of the Levant and sites such as Çayönü Tepesi, Cafer Höyük and Nevalı Çori; they are rarely used in Central Anatolia (Balkan-Ath et al. 
1999.142). This example provides the single convincing case of production for long-distance export in the Neolithic period in Anatolia. The scale of production was unquestionably considerable, and thanks to chemical identification there is no doubt of the provenance of the raw material. The organisation of production and transportation of the products are matters open to debate. The possibilities are numerous in terms of the way that the different geographical areas were in contact; contact may have been directly with envoys moving from one region to another to collect materials, or it may have been via a system of down-the-line trade. The producers themselves may have originated elsewhere and controlled the obsidian sources to their own advantage. It may never be possible to answer the question of how these processes came about, but they certainly involved a level of sophistication with which Neolithic society has rarely been credited.

As a potential example of specialised production, the naviform technique employed at Kaletepe produces robustly positive results in response to the proposed criteria (Tab. 2). The modification of the raw materials is consistent and on a large scale; there is a specific set of technical knowledge associated with the manufacturing process that is not only restricted, but also external to the region as a whole. The production is on a scale that is (according to current archaeological data) unprecedented in Anatolia and the demand, if it was fuelled by external populations, as has been suggested (Balkan-Atl et al. 2001) was both specific in nature and large in scale. There is no doubt that there was a limited number of producers relative to those who, over a wide geographical area, were in receipt of the products, and although it is not clear that the product fulfils a unique function that could not be achieved by other, similar techniques, it was clearly perceived as the most desirable way to achieve this specific functionality at this time. Perhaps the most specific matches with the criteria are in cultural congruency and specific typology, in which form, material, function and style were consistent, and the steps that were taken to achieve the end result were of extraordinary complexity. The type of product that was produced and procured was specific, without any obvious functional benefits when compared to other similar and more locally available technologies. Overall, the naviform production at Kaletepe was overwhelmingly specialised, which is perhaps not a surprising result given the unprecedented organisation and scale of the enterprise. The following example is designed to show the scope of simple criteria to articulate the nuances of a less definite situation in which production was on a very small scale.

\section{Beads}

As an example of potential craft specialisation, beads provide an unusual case study in that their role was probably not directly functional, but rather related to the representation of the individual or the community within wider society. In some instances, beads may have been 'inalienable' goods, attributed a value that was outside of the usual production economy, that would have belonged to a particular individual and been inalienable in ownership and meaning (Clark 2007.29). Examples of these would include the beads that were repaired when broken, such as those seen in the case study used here, beads from the site of Boncuklu Höyük in the Konya Plain (Fig. 1).

Boncuklu Höyük is an early sedentary Neolithic settlement on the Anatolian Plateau, first settled in the late $9^{\text {th }}$ millennium BC and about $9.5 \mathrm{~km}$ from C Catalhöyük (Baird 2009). On-going excavations have produced evidence of all stages of stone bead manufacture from the procurement of raw material from sources in the surrounding landscape to the manufacture, use and discard of the beads, despite the relatively small size of the assemblage (Baysal 2013; Baysal forthcoming $a$ ). The detailed contextual information from the excavation in conjunction with the varied nature of the assemblage renders this an ideal testing ground for craft specialisation theory. Contextual evidence tells a story of production that may have moved dynamically around the site by season; houses would have been preferred in the cold winter months, while the large open areas between the buildings were heavily utilised when the weather permitted. Bead production did not always go according to plan: sometimes a rock or pebble was chosen which was too hard for the available drilling technology. Sometimes a bead blank was abandoned in sheer frustration at the difficulty of piercing it, after several unsuccessful attempts (Baysal 2013). Some manufacturers worked efficiently on a string of bead blanks, which were simultaneously shaped by abrasion, indicating that in at least some cases production probably constituted more than just a hobby. This too could fail; some beads were dropped on the floor and never retrieved, possibly slipping under the dense reed matting that covered almost every surface. Beads were valued at the site; they were rarely included in burials, and even then only in small numbers (Fig. 2). When a bead 
broke, it was usually mended, the sharp edges were rounded off and a new piercing was made so that the bead continued in use. It is not clear how they were worn; there is a single example of three stone beads strung together, although whether as an item of jewellery or decoration on clothing remains unknown. Some beads appear to have had a secondary use as tools; they were grooved from repeated use, perhaps as a cutting surface on which to use an obsidian blade (Baysal 2013) (Fig. 3). Perhaps they were fastened about the body for convenient portability.

When considered in the framework of the parameters for specialisation suggested here (Tab. 2), this assemblage tells us that raw materials were heavily modified - the most basic disc bead of limestone would have taken at least half an hour to produce; the most complex of the beads would have taken hours of work. At least some knowledge of drilling technology would have to have been applied, in conjunction with an understanding of the raw material. This knowledge was not universal; some of those attempting to manufacture beads did not always succeed, so perhaps the knowledge was restricted within the community. Some households show clear evidence of repeated bead manufacture, including concurrent manufacture of a number of beads. There is not enough evidence of the way that the beads were consumed to establish whether this was production within or beyond the household sphere. The fact that beads were curated, mended and re-used as tools and that they were rarely deposited in burials indicates that once manufactured they were regarded as items of either practical, personal or social value. The current evidence from the excavation of Boncuklu Höyük indicates that bead production probably was restricted to certain households within the community, or that perhaps some of the activity took place in communal outdoor areas. The variable levels of skill among those producing the beads also suggest that those who were more proficient carried out the majority of production. Some of the stone beads have clear evidence of a practical purpose and can be interpreted as tools that were worn on the body rather than items purely of personal ornamentation. The recycling of broken beads also indicates that they may have been perceived to have a purpose or value beyond their purely aesthetic quality. The stone disc bead can be seen as the basic unit of Neolithic social identity. It is found at every Neolithic site (e.g., Körtik Tepe, Çatalhöyük, Pınarbaşı; Özkaya, Cossun 2011; Hamilton 2005; Baysal 2013) with little variation except in the stone material

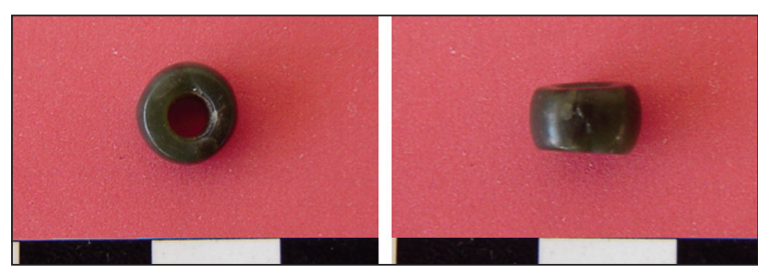

Fig. 2. A high-quality stone disc bead from a burial at Boncuklu Höyük.

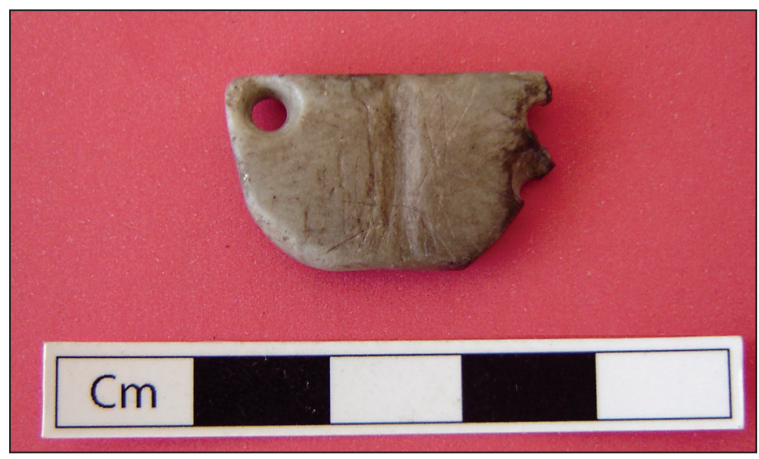

Fig. 3. A stone plaque bead from Boncuklu Höyük, Turkey, showing indications of re-use.

used. Other bead forms can be identified as having a more localized significance; for example, the stone plaques seen at Boncuklu are not paralleled in other central Anatolian sites, including contemporary P1narbaş1 (Baysal forthcoming $b$ ). Through these characterisations it is possible to see a layered identity, which may have extended, consciously or unconsciously, across much of Anatolia. The beads of Boncuklu have a variety of forms and quality. Those that conform to the wider Neolithic typology (e.g., discs and lozenge shapes; Hamilton 2005; Erim-Özdoğan 2011) would have been recognised and accepted over a wide area, whether in terms of trade, exchange or an affinity with the person wearing them. Those that were manufactured for recognition and use within a site such as Boncuklu probably carried more specific messages or practical purposes, the plaque pendants currently being the prime example. Those beads that do not typologically conform are also typically those that are least well formed, technologically poorly executed or not completed.

Overall, the Boncuklu bead assemblage does not currently show conclusive proof of specialisation (Tab. 2 ), although in some respects the specialisation criteria are fulfilled, and indeed further 'high definition' excavation may reveal that there were some individual specialists operating within the community. There is clear evidence of different levels of cultural congruency, suggesting that individuals may have recognised themselves in terms of varying interaction spheres relating to their material environment, 
the largest of which may have extended over much of Anatolia. There are also clear indications that knowledge and know-how may have been restricted to certain individuals within the community, whether this related to those individuals who also owned the necessary toolkits is not yet clear.

\section{Discussion}

Although the parameters for the identification of early craft specialisation that are presented here are (of necessity) relatively basic, they form a system which can be applied regardless of the chronological or geographical setting of an archaeological assemblage and will produce a result which is consistent and comparable. Where previously there has been an implicit difference in the interpretation of archaeological evidence, this methodology requires an author to articulate the reasoning behind their conclusions in a systematic and consistent form and thereby allows others to offer variant interpretations. The discursive system is, inevitably, subjective, but the transparency of the system lies in its basis in archaeological data. Reinterpretation on the basis of new and increasing sources of evidence is important to the success of the scheme. In producing specialisation criteria appropriate to the Neolithic period, it is inevitable that some of the detail that may be desirable in historical or anthropological situations will be lost. However, stripping away the history of archaeological discourse that has led to the overlooking of early craft specialisation reveals the potential utility of a wealth of evidence that can be used to begin a new narrative.

The importance of identifying incipient craft specialisations, and being able to distinguish them from production in general, is inestimable for our understanding of changing social identities and the differentiations that that led to hierarchy. Clark's (2007) contention that "studies of craft specialisation rarely justify their attention to the phenomenon" therefore does not hold true in the case of the Neolithic context presented here. The boundaries between non-specialised and specialised production in its incipient stages are often, although not always, blurred; that there were "transformational process involving skill, aesthetics and cultural meaning" (Costin 2007.146), however, is not in doubt. The methodology highlights the importance of Rosen's (1989.107) assertion that, "...explaining the origins and development of craft specialization as a natural consequence of increasing social complexity ignores the active role that specialization plays in

\begin{tabular}{|c|c|c|}
\hline & $\begin{array}{l}\text { Naviform } \\
\text { technology }\end{array}$ & $\begin{array}{c}\text { Bead } \\
\text { manufacture }\end{array}$ \\
\hline \multicolumn{3}{|c|}{ Prerequisites (assumed to be positive) } \\
\hline Surplus & $\sqrt{ }$ & $\sqrt{ }$ \\
\hline Value & $\checkmark$ & $\checkmark$ \\
\hline Payment & $\checkmark$ & $\checkmark$ \\
\hline \multicolumn{3}{|c|}{ Technology and production } \\
\hline Modification & $\sqrt{ }$ & $\sqrt{ }$ \\
\hline Knowledge & $\checkmark$ & $\checkmark$ \\
\hline Repeated production & $\checkmark$ & $\checkmark$ \\
\hline Demand & $\checkmark$ & $x$ \\
\hline \multicolumn{3}{|l|}{ Social aspects } \\
\hline Producers/consumers & $\sqrt{ }$ & $\mathrm{X}$ \\
\hline Function & $x$ & $x$ \\
\hline Cultural congruency & $\checkmark$ & $\checkmark$ \\
\hline Cultural specificity & $\checkmark$ & $\checkmark$ \\
\hline Overall results & Positive $7 / 11$ & Indeterminate $5 / 11$ \\
\hline
\end{tabular}

Tab. 2. The degree to which the examples used in this article meet the proposed criteria for craft specialisation.

that complexity". Reintegrating the specialist within wider issues of social structure is the next step towards a better understanding of the changing role of the individual in society and the early indicators of social differentiation.

If questions of social evolution have little relevance to the development of incipient specialisations, the significance of the study of the phenomenon must be re-evaluated. However, I believe that the emergence of different roles in society, or a stage at which they become archaeologically visible for the first time, has an important bearing on the way that we view Neolithic society and would also have affected the way that Neolithic populations viewed each other. Specialisation entails the attribution of value (economic or social) to each item and indicates agreements made between those participating in a transaction or social relationship. The production of goods for exchange also provides some of the earliest evidence for long-distance contacts and an insight into the way that Neolithic populations interacted with each other. The knowledge that Neolithic people had of raw materials and the way that procurement and the use of these materials was handled can give clues both to spheres of interaction and to decision making processes. An approach that can integrate all types of specialised craft activity within a wider understanding of society helps archaeological interpretation processes from the level of individual to regional interaction.

The case studies presented here are, of necessity, fairly perfunctory; however, they serve to contrast the 
description of an accepted case of craft specialisation with much more ephemeral evidence from a small community with equivocal indications of social structure in the archaeological record. Does the use of criteria to describe craft specialisation add anything to our understanding? It is perhaps best to view criteria as a way to frame a debate and to ask consistent questions of each data set rather than judging first and describing evidence that fits the judgement. Clark's (2007.21) suggestion to include all production rather than separating and considering specialisation in isolation is indeed valid, given that specialisation must be understood and discussed in the context of that-which-is-not-specialisation.

Craft specialists, ephemeral, individual, talented or exceptionally productive were an important part of Neolithic societies and complex social interactions. The formality of their production areas and the quantity of products should not be assumed. Their strengths may have been in their flexibility, the portability of their skills and their strengths as indivi- duals. The nature of the available evidence may mean that in many instances it will never be possible to determine the exact nature of the specialised activity of a particular community at a particular time. Is there such a thing as a real beginning to craft specialisation or was it an organic process involving thousands of years of work by talented and hardworking individuals? Who is a 'real' specialist? There may be a multitude of opinions about the question, provided there is a framework within which those viewpoints can be compared and contrasted by using a set of parameters which fit the nature of the evidence.
The author would like to thank Douglas Baird, the AHRC, the Prehistoric Society, the British Institute at Ankara, the G. A. Wainwright Fund for Near Eastern Archaeology and Koc University Research Centre for Anatolian Civilizations for supporting various aspects of this research.

\section{References}

Arnold J., Munns A. 1994. Independent or attached specialization: the organization of shell bead production in $\mathrm{Ca}$ lifornia. Journal of Field Archaeology 21: 473-489.

Baird D. 2009. The Boncuklu Project: Investigating the beginnings of agriculture, sedentism and herding in central Anatolia. Anatolian Archaeology 15: 9-10.

Balkan-Atlı N. 2001. Obsidian research in Cappadocia and Kömürcü-Kaletepe obsidian workshop excavation. In 0 . Belli (ed.), Ýstanbul University's Contributions to Archaeology in Turkey (1932-2000). FSF Marbaacilik ve Reklam Hizmetleri. Istanbul: 130-145.

Balkan-Atlı N., Binder D. 2000. L'atelier neolithique de Kömürcü-Kaletepe: fouilles de 1999. Anatolia Antiqua 8: 199-214.

2001. Les ateliers de taille d'obsidienne fouilles de Kömürcü - Kaletepe 2000. Anatolia Antiqua 9: 193-205.

2003. Kaletepe 2002. Anatolia Antiqua 11: 379-383.

Balkan-Atlı N., Binder D. and Kuzucuoğlu C. 1999a. L'atelier néolithique de Kömürcü-Kaletepesi, fouilles de 1998. Anatolica Antiqua 7: 231-243. 1999b. L'atelier neolithique de Kömürcü-Kaletepe: fouilles de 1998. Anatolia Antiqua 7: 231-243.

Balkan-Atlı N., Binder D., Cauvin M.-C. and Faydalı E. 1999. Kömürcü/Kaletepe obsidyen atölyesi 1997 kazıs1. Kazı Sonuçarı Toplantısı 20: 1-21.

2000. Kömürcü/Kaletepe obsidyen atölyesi kazýsý. $K a$ zı Sonucları Toplantısı 21: 41-50.

Balkan-Atlı N., Binder D. and Cauvin M. C. 1999. Obsidian: sources, workshops and trade in central Anatolia. In M. Özdoğan, N. Başgelen (eds.), Neolithic in Turkey. Arkeoloji ve Sanat Yayınları. Istanbul: 133-146.

Balkan-Atlı N., Faydalı E. and Binder D. 2003. Kömürcü/ Kaletepe obsidyen atölyesi kazısı 2001 yılı. Kazı Sonuçları Toplantısı 24: 195-204.

Balkan-Atlı N. 2001. Obsidian research in Cappadocia and Kömürcü-Kaletepe obsidian workshop excavation. In 0. Belli (ed.), Istanbul University's Contributions to Archaeology in Turkey (1932-2000). FSF Marbaacilik ve Reklam Hizmetleri Istanbul: 130-145.

Baysal E. 2013. A tale of two assemblages: early Neolithic manufacture and use of beads in the Konya Plain. Anatolian Studies 63: 1-15. 
forthcoming a. Identity, ornamentation and early specialization: beads from Pinarbașı. In D. Baird (ed.), $P \boldsymbol{l}_{\text {- }}$ narbaşı excavation final publication.

forthcoming $b$. The social life of beads: manufacture and use of beads at Boncuklu Höyük. In D. Baird (ed.), Boncuklu excavation interim publication.

Bender B. 1978. Gatherer-hunter to farmer: a social perspective. World Archaeology 10: 204-222.

Beyer-Honça M. 1995. The Early Neolithic Mortuary Remains from Cayönü: Biological and Social Aspects of Living and Dying in a Village Community. Unpublished $\mathrm{PhD}$ thesis. Indiana University. Indiana.

Binder D. 2002 Stones making sense: What obsidian could tell about the origins of the Central Anatolian Neolithic. In F. Gérard, L. Thissen (eds.), The Neolithic of Central Anatolia. Ege Yayınları. Istanbul: 79-90.

Binder D., Balkan-Atlı N. 2001. Les ateliers de taille d'obsidienne: fouilles de Kömürcü-Kaletepe. Anatolica Antiqua 9: 193-205.

Boone J., Smith A. 1998. Is it evolution yet? A critique of evolutionary archaeology. Current Anthropology 39 (supplement): 141-173.

Brumfiel E., Earle T. (eds.) 1987. Specialization, exchange, and complex societies. Cambridge University Press. Cambridge.

Byrd B. 2005. Reassessing the emergence of village life in the Near East. Journal of Archaeological Research 13 (3): 231-290.

Chapman R. 2003. Archaeologies of Complexity. Routledge. London.

Childe V. G. 1925. The Dawn of European Civilization. Routledge and Kegan Paul. London.

1942. What Happened in History. Penguin Books. London.

1944. Archaeological ages as technological stages. The Journal of the Royal Anthropological Institute of Great Britain and Ireland 74: 7-24.

1958. The Prehistory of European Society. Harmondsworth. London.

Christensen L., Warburton D. 2002. Theories, definitions and goals: obstacles and openings for the understanding of Neolithic ritual. In H. Gebel, H. Hermansen, C. Hoffmann Jensen (eds.), Magic Practices and Ritual in the Near Eastern Neolithic. Ex Oriente. Berlin: 163-170.
Clark J. E. 2007. In Craft Specialization's Penumbra: Things, Persons, Action, Value, and Surplus. Archeological Papers of the American Anthropological Association 17: 20-35.

Clark J., Parry W. 1990. Craft specialisation and cultural complexity. Research in Economic Anthropology 12: 289-346.

Conolly J. 1999. The Çatalhöyük Flint and Obsidian Industry. BAR IS 787. Archaeopress. Oxford.

Costin C. 1986. From chiefdom to empire state: ceramic economy among the prehispanic Wanka of highland Peru. Department of Anthropology. University of California. Los Angeles.

1991. Craft specialisation: issues in defining, documenting, and explaining the organisation of production. In M. Schiffer (ed.), Archaeological Method and Theory. University of Arizona Press. Tucson: 1-56.

Costin C. L. 2007. Thinking about Production: Phenomenological Classification and Lexical Semantics. Archeological Papers of the American Anthropological Association 17: 143-162.

Cross J. 1993. Craft specialisation in nonstratified societies. Research in Economic Anthropology 14: 61-84.

David N., Kramer C. 2001. Ethnoarchaeology in Action. Cambridge University Press. Cambridge.

Dobres M.-A. 2000. Technology and Social Agency. Blackwell. Oxford.

Düring B. 2006. Constructing communities: clustered neighbourhood settlements of the Central Anatolian Neolithic CA. 8500-5500 Cal. BC. Nederlands Instituut Voor Het Nabije Oosten. Leiden.

Erim-Özdoğan A. 2011. Çayönü. In M. Özdoğan, N. Başgelen and P. Kuniholm (eds.), The Neolithic in Turkey Volume 1. Arkeoloji ve Sanat Yayınları. Istanbul: 185-269.

Flad R. K., Hruby Z. X. 2007. 'Specialized' production in archaeological contexts: rethinking specialization, the social value of products, and the practice of production. $A r$ cheological papers of the American Anthropological Association 17: 1-19.

Flanagan J. 1989. Hierarchy in simple 'egalitarian' societies. Annual Review of Anthropology 18: 245-266.

Fried M. H. 1960. On the evolution of social stratification and the state. In S. Diamond (ed.), Culture in History. Columbia University Press. New York: 713-731. 
Giddens A. 1984. The Constitution of Society. Polity Press. Cambridge.

Hamilton N. 2005. The Beads. In I. Hodder (ed.), Changing materialities at Catalhöyük reports from the 19951999 seasons. British Institute at Ankara and McDonald Institute of Archaeological Research. Cambridge and Ankara: 325-332.

Hodder I. (ed.) 1996. On the Surface, Catalhöyük 19935. British Institute of Archaeology at Ankara, McDonald Institute for Archaeological Research. London and Cambridge.

2005. Changing materialities at Catalhöyük. British Institute at Ankara and McDonald Institute for Archaeological Research. Cambridge and Ankara.

Kenoyer J., Vidale M. and Bhan K. 1991. Contemporary stone beadmaking in Khambhat, India: patterns of craft specialisation and organisation of production as reflected in the archaeological record. World Archaeology 23: 44-63.

Kuijt I. 1995. New perspectives on old territories: ritual practices and the emergence of social complexity in the Levantine Neolithic. Unpublished PhD Thesis. Harvard University. Cambridge MA.

Layton R. 1997. An Introduction to Theory in Anthropology. Cambridge University Press. Cambridge.

Özkaya V., Coşkun A. 2011. Körtik Tepe. In M. Özdoğan, N. Başgelen and P. Kuniholm (eds.), The Neolithic in Turkey Volume 1. Arkeoloji ve Sanat Yayınları, Istanbul: 89-127.

Patterson T. 2005. Craft specialization, the reorganization of production relations and state formation. Journal of Social Archaeology 5: 307-337.

Peacock D. 1982. Pottery in the Roman World: an Ethnoarchaeological Approach. Longman. London.

Perlès C. 1992. Systems of exchange and organisation of production in Neolithic Greece. Journal of Mediterranean Archaeology 5: 115-164.

2001. The Early Neolithic in Greece. Cambridge University Press. Cambridge.

Pyburn K. 2004. Ungendering Civilization. Routledge. New York.

Quintero L., Wilke P. 1995. Evolution and economic significance of Naviform core and blade technology? Paleorient 21: 17-33.
Rice P. 1981. Evolution of specialized pottery production: a trial model. Current Anthropology 22(3): 219-240.

Rosen S. A. 1989. The origins of craft specialization: lithic perspectives. In I. Herschkovitz (ed.), People and Culture in Change. British Archaeological Reports 508. Oxford: 107-114.

1997. Lithics after the stone age: a handbook of stone tools from the Levant. AltaMira. Walnut Creek, London and New Delhi.

Rowlands M. 1989. A question of complexity. In D. Miller, M. Rowlands and C. Tilley (eds.), Domination and Resistance. Routledge. London: 29-39.

Salzman P. 1999. Is inequality universal? Current Anthropology 40(1): 31-62.

Schortman E., Urban P. 2004. Modelling the roles of craft production in ancient political economies. Journal of $\mathrm{Ar}$ chaeological Research 12: 185-226.

Sigaut F. 1994. Technology. In T. Ingold (ed.), Companion Encyclopedia of Anthropology. Routledge. London: 420-459.

Stark M. 1991. Ceramic production and community specialisation: a Kalinga ethnoarhaeological study. World $A r-$ chaeology 23: 64-78.

Stein G. 1996. Producers, patrons and prestige: craft specialists and emergent elites in Mesopotamia from 55003100 BC. In B. Wailes (ed.), Craft Specialisation and Social Evolution: in Memory of V. Gordon Childe. University of Pennsylvania. Philadelphia: 25-38.

Tosi M. 1984. The notion of craft specialization and its representation in the archaeological record of early states in the Turanian Basin. In M. Spriggs (ed.), Marxist perspectives in Archaeology. Cambridge University Press. Cambridge: 22-52.

Twigger E. 2009. The Question, Nature and Significance of Neolithic Craft Specialization in Anatolia. Unpublished PhD Thesis. University of Liverpool. Liverpool.

Wiessner P. 2002. The vines of complexity, egalitarian structures and the institutionalisation of inequality among the Enga. Current Anthropology 43: 235-269.

Wright K., Bains R. 2007. Stone bead technology at Çatalhöyük. Online http://www.ctalhoyuk.com/archive_reports/ 2007/ 